\title{
sciendo
}

ACTA UNIVERSITATIS CIBINIENSIS - TECHNICAL SERIES

Vol. 712019

\section{ABRASIVE WATER JET CUTTING OF STAINLESS-STEEL OPTIMIZATION BY ORTHOGONAL ARRAY APPROACH}

\author{
Andrzej Perec \\ The Jacob of Paradies University, Faculty of Technology, 66-400 Gorzów Wielkopolski, Poland \\ Aleksandra Radomska-Zalas \\ The Jacob of Paradies University, Faculty of Technology, 66-400 Gorzów Wielkopolski, Poland
}

\begin{abstract}
The paper presents the use of Taguchi method to optimize the cutting of stainless steel by Abrasive Water Jet. Shown are the influence of the most important machining parameters, such a traverse speed, abrasive grains size and concentration of abrasive in the jet on the maximum depth of cut. Analysis of variance ANOVA was used to determine the effect of machining parameters on the cutting depth. Based on the calculated signal/noise ratios for individual parameters of the cutting process, their impact on cutting depth was determined and optimal process conditions were determined in order to reach the maximum depth of cut. The empirical verification of this process was also performed by comparing the depth of cut predicted and achieved in the tests.
\end{abstract}

\section{Introduction}

Among the modern production technologies, environmentally-friendly ones deserve special attention. It is mostly plastic processing [1,2] and high-pressure water jet technology [3]. Use of conventional coolants in traditional machining and grinding is being looked upon critically from the point of view of its impact on the environment. In water jet machining is used pure (deionized) water with the addition of a small amount of abrasive (17-22 mass\%).

Other advantages of water jet cutting are the possibility of precision processing of complicated contours [4], cutting of different materials [5, 6] and its effectiveness in conditions danger of fire or detonation , and even possibility work underwater [7]. Further favors of the cutting of materials by a high-pressure water jet contain:

- the proper surface structure after machining,

- the structure of the cut material is thermally unaffected,

- no inner stresses in the cutting sphere,

- water jet can be manipulated very easily.

However, the application of a plain water jet is not effective in case of cutting hard materials such as rocks or metals. The insertion of a loose abrasive to the jet successfully intensifying the erosive abilities.

High-pressure water jet cutting technique is an advanced method of separating materials. Processing materials using a high-pressure abrasive water jet is more complex than conventional treatments. Water under high-pressure is transformed inside a nozzle to a high-speed jet, flows out with almost $800 \mathrm{~m} / \mathrm{s} \mathrm{speed}$ and hits a stream of abrasive particles and accelerates them to high speed.

Addition of dry abrasive grains to the jet in a mixing chamber of cutting head rises cutting efficiency [4]. As an effect, it is possible to cut each material. General pressure height of the abrasive water jet (AWJ) system range from 400 to $600 \mathrm{MPa}$. The most generally used abrasives material is garnet as indicated in [8-10].

One of the directions of determining the influence of process parameters on its effectiveness is using the orthogonal array approach, called from the name of the author as Taguchi method [11, 12]. This approach provides limiting the amount of research required to reach the study results, thereby decreasing the cost and the time required to carry them out. The Taguchi signal/noise $(\mathrm{S} / \mathrm{N})$ ratio lets the valuation of the relevance of the influence of diverse factors on the tested process, which is not understood.

The cutting depth is the best parameter, characterizing the water jet cutting process. The high cutting depth enables efficient cutting. For this reason, ratio $\eta(\mathrm{S} / \mathrm{N})$ "bigger is better" represented by the equation (1) was selected for further analysis. 
Where:

$$
\eta=-10 \log \left(\frac{1}{n} \sum_{i=1}^{n} \frac{1}{y_{i}^{2}}\right)
$$

$\mathrm{n}$ - the number of iterate at the same circumstances,

$\mathrm{y}$ - the examined measurement result,

$\mathrm{i}$ - the number of orthogonal array variables.

The fundamental rule of the design experiment is to optimized product quality to come insensitive hesitations in each example without exception [13].

Taguchi experimental design approach needs the statement of the problem, determine a set of parameters and variables, especially taking into account their number, and selection of suitable orthogonal array. The next step is performing the planned tests and choice of the parameters optimal values to check the effects. To evaluate the quality the $\mathrm{S} / \mathrm{N}$ ratio is used. Maximizing the $\mathrm{S} / \mathrm{N}$ ratio causes reduce the loss function. The higher the value of $\mathrm{S} / \mathrm{N}$, the larger is also the resistance to distortions [14].

\section{Materials and methods}

The study was conducted on the test stand, using a high pressure KMT intensifier type I50, 2 axis CNC machine type ILS55 by Techni Waterjet controlled by computer system shown (Fig. 1). The maximum working pressure is $400 \mathrm{MPa}$ at a flow rate $5 \mathrm{dm}^{3} / \mathrm{min}$. The cutting head is appointed with a diamond water nozzle with a diameter of $0.25 \mathrm{~mm}$, and a focusing tube with a diameter of $0.76 \mathrm{~mm}$ and a length of $75 \mathrm{~mm}$.

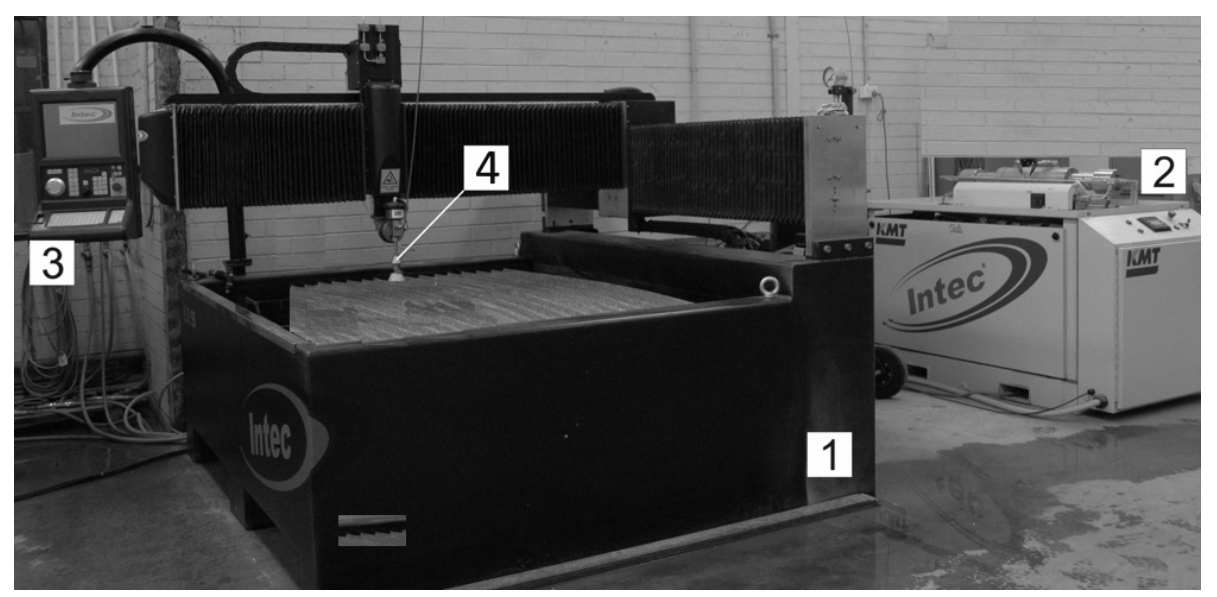

Fig. 1. Test stand: 1) Cutting machine, 2) Intensifier, 3) Control Unit,4) Cutting Head.

In tests the garnet abrasive was used. The garnet group contains closely related, isomorphs minerals that may intergrowth or contain a slight percentage of another element found in a different garnet member replacing one of its own. Almandine is the iron aluminum garnet. The garnet class contains closely associated, isomorphic minerals that may grow into each other or contain a small quantity of components from other garnets which substitute for the original. Garnets are isostructural, meaning they have the same crystalline structure resulting in similar crystal shapes and properties (Tab. 2). Almandine $\left(\mathrm{Fe}_{2}+3 \mathrm{Al}_{2}\right.$ $\left.\left[\mathrm{SiO}_{4}\right]_{3}\right)$ is the most popular form of garnet used in AWJ technology. The properties of garnet abrasives and schematic view of its crystal shape are presented in Table 1.

Table 1. Almandine garnet properties [15]

\begin{tabular}{|l|l|}
\hline & \\
\hline Crystal system & Cubic \\
\hline Twinning & None \\
\hline Unit cell & \begin{tabular}{l} 
a $=11.53 \AA$ \\
\hline Habit
\end{tabular} \\
\hline Cleavage & $\begin{array}{l}\text { Crystals usually dodecahedrons or trapezohedrons; also in } \\
\text { combination or with hexocathedron; massive; granular }\end{array}$ \\
\hline
\end{tabular}




\begin{tabular}{|l|l|}
\hline Fracture & Conchoidal to uneven \\
\hline Tenacity & Brittle \\
\hline Color & $\begin{array}{l}\text { Deep red to reddish-brown, sometimes with a violet or brown } \\
\text { or brownish black hue }\end{array}$ \\
\hline $\begin{array}{l}\text { Hardness } \\
\text { (Mohs) }\end{array}$ & $6.5-7.5$ \\
\hline Density & $4.1-4.3 \mathrm{~kg} / \mathrm{dm}^{3}$ \\
\hline
\end{tabular}

In research alluvial almandine garnet from Western Australia (GMA garnet) deposit was used. The sample view of fraction are presented in Fig. 2 and particle grain distribution are shown in Fig. 3.
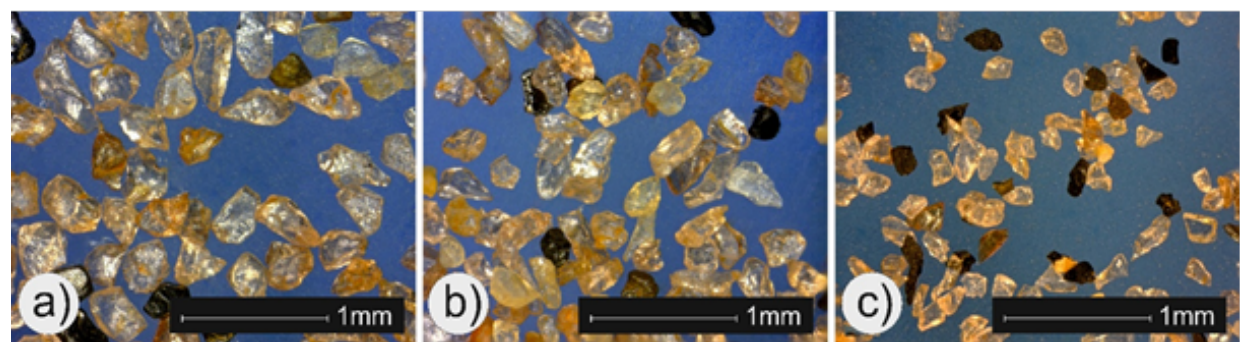

Fig. 2. The microscopic view of garnet abrasives: a) GMA80, b) GMA90, GMA150.

The cut material, stainless steels $316 \mathrm{SS}$ (X5 CrNiMo 17 12 2) is a molybdenum-alloyed steel and is the second most common austenite stainless steel (after grade 304). It is the preferred steel for use in marine environments because of its greater resistance to pitting corrosion than other grades of steel.

a)

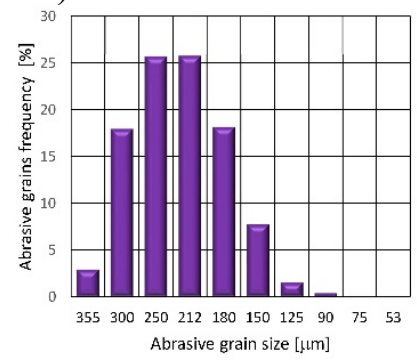

b)

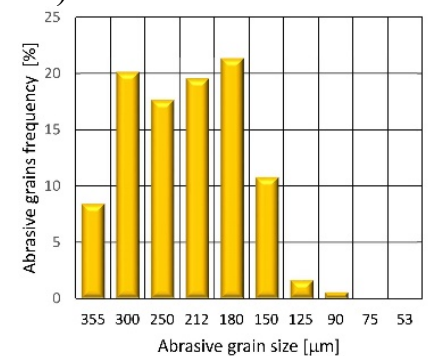

c)

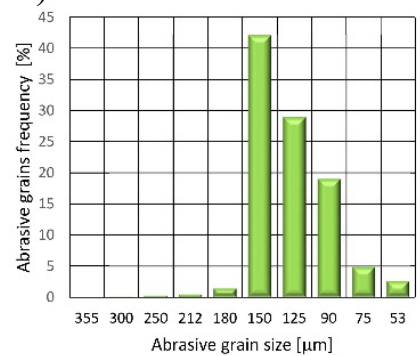

Fig. 3. Particle grain distribution for tested abrasives: a) GMA80, b) GMA90, GMA150

The 316 stainless steel is used in boat fittings, coastal architectural paneling, railings and trim, chemical containers, including for transport, food preparation equipment particularly in chloride environments, laboratory benches and equipment, heat exchangers, woven or welded screens for mining, quarrying and water filtration, threaded fasteners and springs.

\section{Test procedure}

Cutting of materials was made by directing the jet perpendicular to the workpiece (Fig. 4) and causing its linear displacement relative to the working nozzle [16].

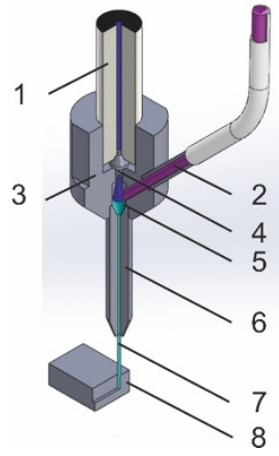

Fig. 4. Schematic view of AWJ cutting: 1) high-pressure water inlet, 2) dry abrasive inlet, 3) cutting head body, 4) water nozzle, 5) mixing chamber, 6) focusing tube, 7) AWJ, 8) sample 
The thickness of the cut samples of the materials was chosen so that the most effective machining parameters did not result in full cutting, which could make it difficult to correctly determine the cutting depth. Process parameters such as pressure of water, stand-off distance, traverse speed, abrasive concentration and abrasive size were chosen based on our previous works $[5,14]$ and the papers of other researchers: Hocheng et al. [17] Hreha et al. [18], Supriya and Srinivas [19]. The cutting process conducted under $400 \mathrm{MPa}$ pressure and with $4 \mathrm{~mm}$ stand-off distance and the following parameters (Table 2):

- Traverse speed: $2 ; 4$ and $6 \mathrm{~mm} / \mathrm{sec}$,

- The concentration of abrasive in the jet: $17.5 ; 20 ; 22.5 \%$ (by weight),

- Garnet grains fraction \#80 (G80), \#90 (G90) and \#150 (G150).

For the calculation procedure, the Minitab software was utilized. Approach parameters and values are presented in Table 2.

Table 2 Parameters and values of abrasive water jet cutting process.

\begin{tabular}{|c|c|c|c|}
\hline \multirow{2}{*}{ Parameters } & \multicolumn{3}{|c|}{ Values } \\
\cline { 2 - 4 } & $\mathbf{1}$ & $\mathbf{2}$ & $\mathbf{3}$ \\
\hline Traverse speed [mm/s] & 2 & 4 & 6 \\
\hline $\begin{array}{c}\text { Abrasive concentration } \\
{[\%]}\end{array}$ & 17.5 & 20.0 & 22.5 \\
\hline Abrasive & GMA garnet \#80 & GMA garnet \#90 & GMA garnet \#150 \\
\hline
\end{tabular}

Without design of experiment requires tests number is 27 (three sizes of the three levels $-3^{3}$ ). The use of the Taguchi array (orthogonal) will reduce the number of required tests to 9 plus one test for the verification of optimum.

Table 3 presents the parameters of the cutting process and the ratio signal $/$ noise ratio $\mathrm{S} / \mathrm{N}$ reached for the output parameter - the maximum cutting depth.

Table 3 Parameters of designed experiment, responses and values of $\mathrm{S} / \mathrm{N}$ ratio.

\begin{tabular}{|c|c|c|c|c|c|}
\hline $\begin{array}{c}\text { Test } \\
\text { no }\end{array}$ & $\begin{array}{c}\text { Traverse } \\
\text { speed }\end{array}$ & $\begin{array}{c}\text { Abrasive } \\
\text { concentration }\end{array}$ & Abrasive & $\begin{array}{c}\text { Cutting } \\
\text { depth }\end{array}$ & $\begin{array}{c}\text { S/N ratio for } \\
\text { cutting } \\
\text { depth }\end{array}$ \\
\hline & {$[\mathrm{mm} / \mathrm{s}]$} & {$[\%]$} & & {$[\mathrm{mm}]$} & $\eta$ \\
\hline 1 & 2 & 17.5 & GMA80 & 19.30 & 25.7111 \\
\hline 2 & 2 & 20.0 & GMA90 & 18.33 & 25.2632 \\
\hline 3 & 2 & 22.5 & GMA150 & 15.50 & 23.8066 \\
\hline 4 & 4 & 17.5 & GMA90 & 12.97 & 22.2588 \\
\hline 5 & 4 & 20.0 & GMA150 & 12.60 & 22.0074 \\
\hline 6 & 4 & 22.5 & GMA80 & 14.81 & 23.4111 \\
\hline 7 & 6 & 17.5 & GMA150 & 8.30 & 18.3816 \\
\hline 8 & 6 & 20.0 & GMA80 & 10.79 & 20.6604 \\
\hline 9 & 6 & 22.5 & GMA90 & 8.66 & 18.7504 \\
\hline
\end{tabular}

\section{Results and discussion}

The result of the $\mathrm{S} / \mathrm{N}$ ratio of traverse speed on the cutting depth is conversely proportional (Fig. 5). The maximum $\mathrm{S} / \mathrm{N}$ ratio is reached for the traverse speed of $2 \mathrm{~mm} / \mathrm{s}$. The feed rate has the biggest impact on the ratio $\mathrm{S} / \mathrm{N}$ (Rank 1, Delta 5.66 in Tab. 4).

Table 4 Response Table for S/N Ratios "Larger is better"

\begin{tabular}{|c|c|c|c|}
\hline & $\begin{array}{c}\text { Traverse } \\
\text { speed }\end{array}$ & Concentration & $\begin{array}{c}\text { Abrasive } \\
\text { size }\end{array}$ \\
\hline Level & {$[\mathrm{mm} / \mathrm{s}]$} & {$[\%]$} & \\
\hline 1 & 24.93 & 22.12 & 23.26 \\
\hline 2 & 22.56 & 22.64 & 22.09 \\
\hline 3 & 19.26 & 21.99 & 21.40 \\
\hline Delta & 5.66 & 0.65 & 1.86 \\
\hline Rank & 1 & 3 & 2 \\
\hline
\end{tabular}


The second biggest parameter affecting the $\mathrm{S} / \mathrm{N}$ ratio for the cutting depth is the size of abrasive (Rank 2; Delta 1.86). The largest value of this ratio obtains for the largest garnet grains - GMA\#80. The third parameter, the concentration of abrasive in the jet has the lowest impact (Rank 3, Delta 0.65) on the S/N ratio. Its maximum occurs on a stream of the abrasive concentration of $20 \%$. The analysis of variance ANOVA is used to find out the machining parameters influence on cutting depth. The analysis was carried out for a $95 \%$ confidence level (Table 5).

Table 5 ANOVA table for cutting depth

\begin{tabular}{|l|c|r|r|r|r|}
\hline Source & DF & \multicolumn{1}{c|}{ Adj SS } & \multicolumn{1}{c|}{ Adj MS } & F-Value & P-Value \\
\hline Traverse speed [mm/s] & 2 & 107.358 & 53.6791 & 133.89 & 0.007 \\
\hline Concentration [\%] & 2 & 1.272 & 0.6358 & 1.59 & 0.387 \\
\hline Abrasive size & 2 & 12.147 & 6.0737 & 15.15 & 0.062 \\
\hline Error & 2 & 0.802 & 0.4009 & & \\
\hline Total & 8 & 121.579 & & & \\
\hline
\end{tabular}

$\mathrm{S}=0.633193 \mathrm{R}-\mathrm{sq}=99.34 \% \mathrm{R}-\mathrm{sq}(\mathrm{adj})=97.36 \% \mathrm{SS}$ - sum of squares, DF - degree of freedom, MS - mean square, and F ratio of variance of a source to variance of error.

It was observed that traverse speed is the most significant control factor influencing on the assessment of cutting depth. Meanwhile abrasive size respectively have sub significant effect on cutting depth. Abrasive concentration is the least significant in influencing on cutting depth.

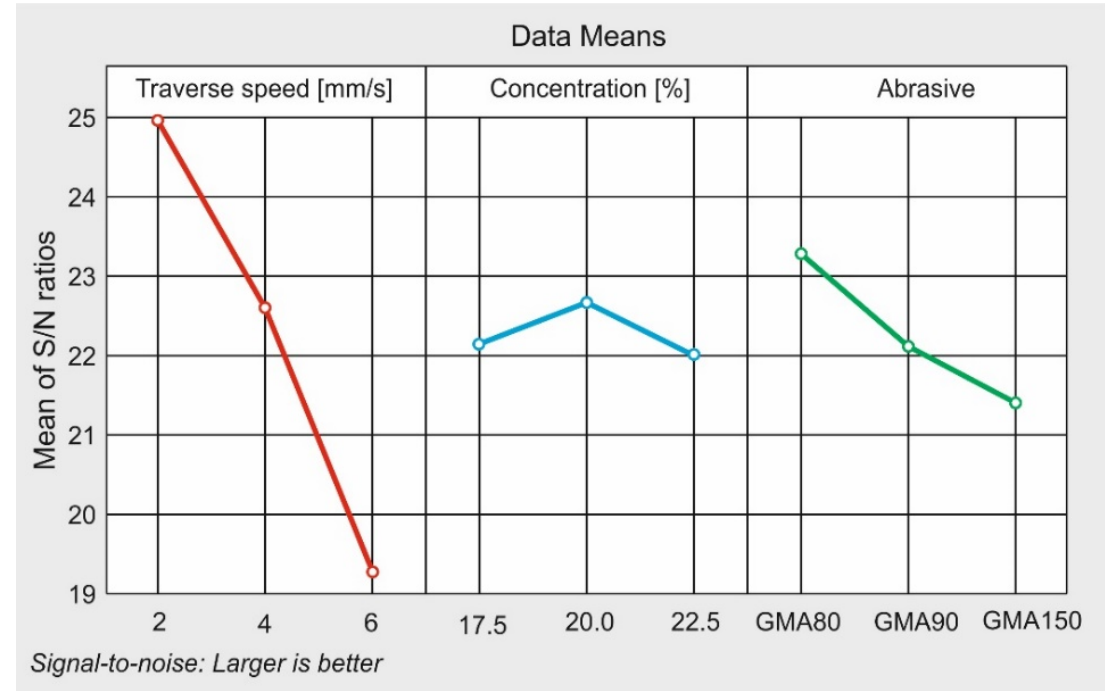

Fig. 5. S/N ratio for tested parameters.

Additionally in the Table 6 are presented the predicted and empirically obtained values depth of cut in optimal condition: traverse speed equals $2 \mathrm{~mm} / \mathrm{s}$, abrasive grain size equal \#80 (212 to $180 \mathrm{~m})$ and abrasive concentration in the jet equal $20 \%$

Table 6. The predicted and Empirically obtained depth of cut reached under optimal conditions

\begin{tabular}{|c|c|c|}
\hline $\begin{array}{c}\text { Traverse } \\
\text { speed }\end{array}$ & Concentration & $\begin{array}{c}\text { Abrasive } \\
\text { size }\end{array}$ \\
\hline$[\mathbf{m m} / \mathbf{s}]$ & {$[\%]$} & \\
\hline 2 & 20 & $\# 80$ \\
\hline \hline \multicolumn{2}{|c|}{ Predicted depth of cut } & $19.64 \mathrm{~mm}$ \\
\hline $\begin{array}{c}\text { Empirically obtained depth of } \\
\text { cut }\end{array}$ & $19.79 \mathrm{~mm}$ \\
\hline
\end{tabular}

The difference between predicted and empirically obtained values does not exceed $1 \%$. This certifies the validity of using the Taguchi approach to optimization. 


\section{Summary}

The Taguchi approach can be a convenient alternative, especially when cutting unusual materials. It can very simplify the research process decreasing the time to acquire reliable outcomes and lowered the tests cost because it reduces the number of tests needed. It also identifies control parameters irrelevant in the cutting process.

One of the limitations of this method is the necessity of planning only for discrete values of control parameters.

The further issue is the reaction of the analyzed processes, especially non -linear functions of their parameters, which puts into question mark the proper use of orthogonal arrays, proposed in the Taguchi approach.

The method can be especially useful in the design of experiment on the machining of new materials, with insufficient information on the process parameters.

\section{References}

1. L. Kukiełka et al., "Analysis of the States of Deformation and Stress in the Surface Layer of the Product after the Burnishing Cold Rolling Operation," Materials Science Forum, vol. 862 (2016), pp. 278-287.

2. R. Patyk et al., "Experimental and numerical researches of duplex burnishing process in aspect of achieved productive quality of the product," AIP Conference Proceedings, vol. 1960, no. 1, (2018) p. 070021.

3. A. Perec, "Environmental Aspects of Abrasive Water Jet Cutting," Annual Set The Environment Protection - Rocznik Ochrona Srodowiska, vol. 20 (2018), pp. 258-274.

4. J. Valíček, S. Hloch, and D. Kozak, "Surface geometric parameters proposal for the advanced control of abrasive waterjet technology," The International Journal of Advanced Manufacturing Technology, vol. 41, no. 3-4, (2009) pp. 323-328.

5. A. Perec, "Experimental research into alternative abrasive material for the abrasive water jet cutting of titanium," Int. J. Adv. Manuf. Technol., vol. 97, no. 1-4, (2018), pp. 1529-1540.

6. P. D. Unde, M. D. Gayakwad, N. G. Patil, R. S. Pawade, D. G. Thakur, and P. K. Brahmankar, "Experimental Investigations into Abrasive Waterjet Machining of Carbon Fiber Reinforced Plastic," Journal of Composites, 2015. [Online]. Available: https:/www.hindawi.com/journals/ jcomp/2015/971596/. [Accessed: 06-Jul-2018].

7. D. G. Alberts and M. Hashish, "Evaluation of submerged high-pressure waterjets for deep ocean applications," in Proceedings of the Sixth (1996) International Offshore and Polar Engineering Conference, Vol I, 1996, J. S. Chung, B. M. Das, and J. Roesset, Eds. Cupertino: International Society Offshore\& Polar Engineers, (1996), pp. 46-50.

8. J. Foldyna, P. Martinec, and L. Sitek, "Testing of mineral typed of abrasives for abrasive water jet cutting," in 2001 WJTA American Waterjet Conference. Minneapolis, Minnesota, USA, 2001, Paper 22.

9. S. Hloch and J. Valicek, "Significance of Barton Garnet and Olivine Evaluation at Abrasive Waterjet Cutting by Factor Analysis," Nonconventional Technologies Review, no. 4, (2007), pp. 25-30.

10. D. Kinik, B. Gánovská, S. Hloch, P. Monka, K. Monková, and Z. Hutyrová, "On-line monitoring of technological process of material abrasive water jet cutting | On-line praćenje tehnološkog postupka rezanja materijala abrazivnim vodenim mlazom," Techničky vjesnik, vol. 22, no. 2, (2015), pp. 351357.

11. M. Tavodová, "The surface quality of materials after cutting by abrasive water jet evaluated by selected methods," Manufacturing Technology, vol. 13, no. 2, (2013), pp. 236-241.

12. V. Sharma, S. Chattopadhyaya, and S. Hloch, "Multi response optimization of process parameters based on Taguchi-Fuzzy model for coal cutting by water jet technology," International Journal of Advanced Manufacturing Technology, vol. 56, no. 9-12, (2011), pp. 1019-1025.

13. A. Perec, "Abrasive suspension water jet cutting optimization using orthogonal array design," Procedia Engineering, vol. 149, (2016), pp. 366-373.

14. A. Perec, F. Pude, M. Kaufeld, and K. Wegener, "Obtaining the Selected Surface Roughness by Means of Mathematical Model Based Parameter Optimization in Abrasive Waterjet Cutting," Strojniški vestnik - Journal of Mechanical Engineering, vol. 63, no. 10, (2017), pp. 606-613. 
15. P. Martinec, J. Foldyna, L. Sitek, J. Ščučka, and J. Vašek, "Abrasives for AWJ cutting. INCOCOPERNICUS," Institute of Geonics, Ostrava, 2002, ISBN 80-86407-02-0, 2002.

16. A. Perec, "Investigation of Limestone Cutting Efficiency by the Abrasive Water Suspension Jet," in Advances in Manufacturing Engineering and Materials: Proceedings of the International Conference on Manufacturing Engineering and Materials (ICMEM 2018), 18-22 June, 2018, Nový Smokovec, Slovakia, S. Hloch, D. Klichová, G. M. Krolczyk, S. Chattopadhyaya, and L. Ruppenthalová, Eds. Springer International Publishing, 2019.

17. H. Hocheng and M. Y. Hsu, "Erosion wear of stainless steel by abrasives entrained in a water jet," Arabian Journal for Science and Engineering, vol. 25, no. 2, (2000) pp. 187-202.

18. P. Hreha, S. Hloch, and V. Peržel, "Analysis of acoustic emission recorded during monitoring of abrasive waterjet cutting of stainless steel AISI 309," Tehnički vjesnik, vol. 19, no. 2, (2012) pp. 355359.

19. S. B. Supriya and S. Srinivas, "Machinability Studies on Stainless Steel by Abrasive Water Jet Review," Materials Today: Proceedings, no. 5, (2018), pp. 2871-2876. 